\title{
THE GROWTH PATTERNS OF CARCASS TISSUES WITHIN WHOLESALE CUTS IN FATTENING STEER
}

\author{
R. Priyanto ${ }^{1}$, E. R. Johnson ${ }^{2}$ and D.G. Taylor ${ }^{3}$ \\ ${ }^{1}$ Faculty of Animal Sciences, Bogor Agricultural University \\ Jl. Agatis, Darmaga Campus, Bogor 16680 - Indonesia \\ ${ }^{2}$ School of Veterinary Science, The University of Queensland \\ Kenmore, Qld 4069, Australia \\ ${ }^{3}$ Department of Animal Production, The University of Queensland \\ Gatton College, Lawes, Qld 4343, Australia \\ Corresponding e-mail: rd.priyanto@gmail.com
}

Received April 15, 2009; Accepted August 11,2009

\begin{abstract}
An investigation was conducted on beef carcasses, aimed at identifying the growth patterns of wholesale cuts and their tissues in steer during fattening phase. This study involved 69 grass-fed steers with a liveweight range of 300 to $600 \mathrm{~kg}$. They had entered, or were progressing along, their fat deposition phase. An allometric model (Huxley, 1932) was used to study the growth patterns of carcass tissues within wholesale cuts. In general, The growths of muscle and fat within wholesale cuts followed similar patterns. Some differences in growth patterns between muscle and fat were identified on the dorsal region. The growth impetus for fat moved from the thoracic backwards to the lumbar region which was the reverse of the growth impetus for muscle. Differential growth patterns occurred between intermuscular (IM) fat and subcutaneous (SC) fat. With IM fat, its growth movement was similar to that of total fat where there was a concentration of growth in the lumbar area and thin flank as side weight increased. With SC fat, there were growth movements from the ventral region to the dorsal region of the carcass. Bone growth within wholesale cuts showed a less clear pattern.
\end{abstract}

Keywords : Fattening Phase, Steer, Growth Pattern, Carcass Tissue, Wholesale Cut.

\section{INTRODUCTION}

In growth studies, it is common to relate tissue weight in wholesale cuts to the respective total carcass tissue weight. This technique has long been established and provided a useful interpretation of the growth and distribution of muscle, fat and bone throughout the carcass (Berg et al., 1978ab; Jones et al., 1978; Jones et al., 1980ab). It is of particularly important in growth studies of muscle, fat and bone within the wholesale cuts were related to carcass weight. Using this regressor, the growth patterns among carcass tissues within wholesale cut could be examined simultaneously and this, in turn, could have major commercial implications since carcass weight is commonly used as a basis of beef carcass evaluation (Johnson et al., 1997; Priyanto et al. 1997; Priyanto et al., 2005; Hafid and Priyanto, 2006). The use of carcass weight in growth studies allows both the growth and distribution of wholesale cuts and their tissues to be examined and therefore the changes in the weights of wholesale cuts could be explained in terms of muscle, fat and bone (Priyanto et al., 1999). The following study was undertaken to examine the growth patterns of carcass tissues within wholesale cuts relative to the growth of carcass side in fattening steer.

\section{MATERIALS AND METHODS}

\section{Cattle and Procedures}

This study involved 69 grass-fed steers, comprising 23 Brahmans, 24 Herefords and 22 Brahman x Hereford F1 Crosses which had enter, or were progressing along, their fat deposition phase. The steers were sequentially slaughtered at approximately 300, 400, 500 and $600 \mathrm{~kg}$ live-weight. 
All steers were fasted but access to water 24 hours prior to slaughter. Following dressing, the carcasses were divided into two sides, weighed and then chilled at $3^{0} \mathrm{C}$ for 24 hours. The right sides were broken down into 15 wholesale cuts, namely Thin flank, Loin, Tenderloin, Rump, Thick flank, Topside, Silverside, Shank, PE Brisket, NE Brisket, Shin, Blade, Rib Set, Chuck, Neck+Sticking (AUS-MEAT, 1998). The cuts were then dissected into muscle, fat, intermuscular (IM) and subcutaneous (SC) fats, bone and connective tissue. Weights were recorded for carcass sides (hot and chilled), wholesale cuts and dissection products.

\section{Data Analysis}

An allometric model, $\mathrm{Y}=\mathrm{a} \mathrm{X}^{\mathrm{b}}$ (Huxley, 1932) was used to study the growth patterns of wholesale cuts and their tissues. In order to obtain a linear relationship, the equation was transformed into log natural form and the linear regression was analyzed according to Draper and Smith (1981), as follow:

$$
\ln Y_{i j}=\ln a+b \ln X_{i j}+E_{i j}
$$

where

$Y_{i j}=$ weight of wholesale cut, or its tissues components of the $j^{\text {th }}$ animal from the $i^{\text {th }}$ breed

$a=$ intercept

$X_{i j}=$ side carcass weight of the $j^{\text {th }}$ animal from the $i^{\text {th }}$ breed

$b=$ regression coefficient of $\mathrm{Y}_{\mathrm{ij}}$ on $\mathrm{X}_{\mathrm{ij}}$

$E_{i j}=$ residual error of the measurement of $\mathrm{Y}_{\mathrm{ij}}$ assumed to be normally distributed around a mean of zero with a variance of ó $^{2}$

\section{RESULTS AND DISCUSSION}

The general means of the weights of the 15 wholesale cuts and their tissue weights are summarised in Table 1. The wide range of carcass weights studied was reflected in the high standard deviation of the means of all wholesale cuts. It was particularly important that this was so in order to obtain meaningful growth data especially when the tissue weights within wholesale cuts were related to side weight. Blade constituted the biggest cut of the carcass and had the greatest muscle content.
After blade, the other cuts in descending order of muscle content were Topside, Chuck, Silverside, Rump, Loin, Neck+Sticking, Thick Flank and Rib Set. Individually, Shank, NE Brisket, PE Brisket, Shin, Thin Flank and Tenderloin contained relatively small amounts of carcass muscle. Thin Flank and Brisket (PE and NE) were the cuts with most potential to deposit fat. The greatest deposition of intermuscular fat occurred mainly in forequarter cuts such as Rib Set, Blade, Chuck and Neck+Sticking; the greatest deposition of subcutaneous fat took place in hindquarter cuts such as Topside, Silverside, Thick Flank and Rump. Loin showed a high potential for both SC fat and IM fat deposition.

\section{Developmental Changes Occurring in the Carcass Tissues}

The growths of muscle, fat, IM fat, SC fat and bone within wholesale cuts relative to the growth of carcass side were described by allometric relationship. Regression analysis showed that all the growth coefficients were highly significant $(\mathrm{P}<0.01)$. Fats within wholesale cuts had the highest coefficients, followed by muscle and bone (Figure 1, 2 and 3). When the fat was partitioned into IM fat and SC fat, the growth coefficients of SC fat were generally higher than that of IM fat, indicating the earlier maturity of IM fat and the later maturity of SC fat (Belk et al., 1991).

As shown in Figure 1, commencing at the Shank, the growth impetus of muscle moved to the proximal hind-limb region (Silverside and Rump). Dorsally, the growth wave moved from the Loin towards the proximal fore-limb region ( $\mathrm{Rib}$ Set and Chuck). Along the ventral line, there was a growth movement from the Shin toward the NE Brisket. Thus, there were two points of muscle growth concentration within wholesale cuts, one in the Rib Set and one in NE Brisket.

The growth of total fat also commenced in the leg regions. The growth impetus moved from the Shank to the proximal hind-limb (Silverside) and from the Shin to the neck region (Figure 2). There was a centripetal movement of the two waves intercepting in the lumbar region (Loin) and ending in the abdominal region (Thin Flank). Thus, a concentration of total fat growth occurred in the lumbar and abdominal regions as the animals became heavier. Differential growth patterns occurred between IM fat and SC fat. Both IM fat and SC fat had their lowest growth coefficients in the Shin and Shank. With IM fat, its growth movement was similar to that of 
Table1. Means and Standard Deviations of the Weights of the Wholesale Cuts and Their Tis sues

\begin{tabular}{|c|c|c|c|c|c|c|c|c|c|c|c|c|}
\hline \multirow{3}{*}{ Items } & \multicolumn{12}{|c|}{ Weight $(\mathrm{kg})$} \\
\hline & \multicolumn{2}{|c|}{ Wholesale cut } & \multicolumn{2}{|c|}{ Muscle } & \multicolumn{2}{|c|}{ Fat } & \multicolumn{2}{|c|}{ IM fat } & \multicolumn{2}{|c|}{ SC fat } & \multicolumn{2}{|c|}{ Bone } \\
\hline & Mean & SD & Mean & SD & Mean & SD & Mean & SD & Mean & SD & Mean & SD \\
\hline Thin Flank & 4.56 & 1.82 & 2.22 & 0.64 & 2.02 & 1.22 & 0.98 & 0.68 & 1.04 & 0.65 & - & - \\
\hline Loin & 10.89 & 3.66 & 6.14 & 1.63 & 2.87 & 1.83 & 1.42 & 0.77 & 1.45 & 1.10 & 1.78 & 0.44 \\
\hline Tenderloin & 2.74 & 0.75 & 2.21 & 0.56 & 0.51 & 0.23 & 0.51 & 0.23 & - & - & - & - \\
\hline Rump & 10.24 & 3.23 & 6.52 & 1.75 & 2.07 & 1.22 & 0.90 & 0.41 & 1.16 & 0.86 & 1.53 & 0.42 \\
\hline Thick Flank & 5.84 & 1.45 & 4.59 & 1.08 & 1.02 & 0.41 & 0.37 & 0.15 & 0.65 & 0.32 & 0.13 & 0.02 \\
\hline Topside & 9.47 & 2.56 & 7.35 & 1.65 & 2.04 & 1.04 & 0.63 & 0.35 & 1.41 & 0.78 & - & - \\
\hline Silverside & 8.11 & 2.41 & 6.56 & 1.66 & 1.50 & 0.81 & 0.57 & 0.26 & 0.93 & 0.60 & $2.67^{\dagger}$ & 0.50 \\
\hline Shank & 6.76 & 1.36 & 3.53 & 0.76 & 0.87 & 0.31 & 0.37 & 0.16 & 0.51 & 0.26 & 1.88 & 0.32 \\
\hline PE Brisket & 6.30 & 2.20 & 3.02 & 0.89 & 2.44 & 1.21 & 1.23 & 0.54 & 1.20 & 0.83 & 0.82 & 0.23 \\
\hline NE Brisket & 6.23 & 2.28 & 3.17 & 0.97 & 2.11 & 1.19 & 1.68 & 0.93 & 0.43 & 0.31 & 0.89 & 0.22 \\
\hline Shin & 5.17 & 1.29 & 2.43 & 0.68 & 0.66 & 0.28 & 0.35 & 0.16 & 0.31 & 0.15 & 1.80 & 0.34 \\
\hline Blade & 14.48 & 4.05 & 10.12 & 2.70 & 2.00 & 0.99 & 1.15 & 0.47 & 0.85 & 0.57 & 2.20 & 0.47 \\
\hline Rib Set & 7.34 & 2.48 & 4.23 & 1.30 & 1.61 & 0.92 & 1.29 & 0.68 & 0.32 & 0.28 & 1.40 & 0.39 \\
\hline Chuck & 10.53 & 3.48 & 7.01 & 2.34 & 1.80 & 0.83 & 1.67 & 0.77 & 0.13 & 0.15 & 1.51 & 0.46 \\
\hline Neck & 8.91 & 2.68 & 5.86 & 1.73 & 1.64 & 0.81 & 1.26 & 0.58 & 0.38 & 0.29 & 1.22 & 0.30 \\
\hline Total & 121.22 & 34.92 & 75.41 & 19.49 & 25.55 & 12.75 & 14.74 & 6.55 & 10.80 & 6.50 & 17.81 & 3.78 \\
\hline
\end{tabular}

$\dagger$ Femur bone regarded as hindquarter bone

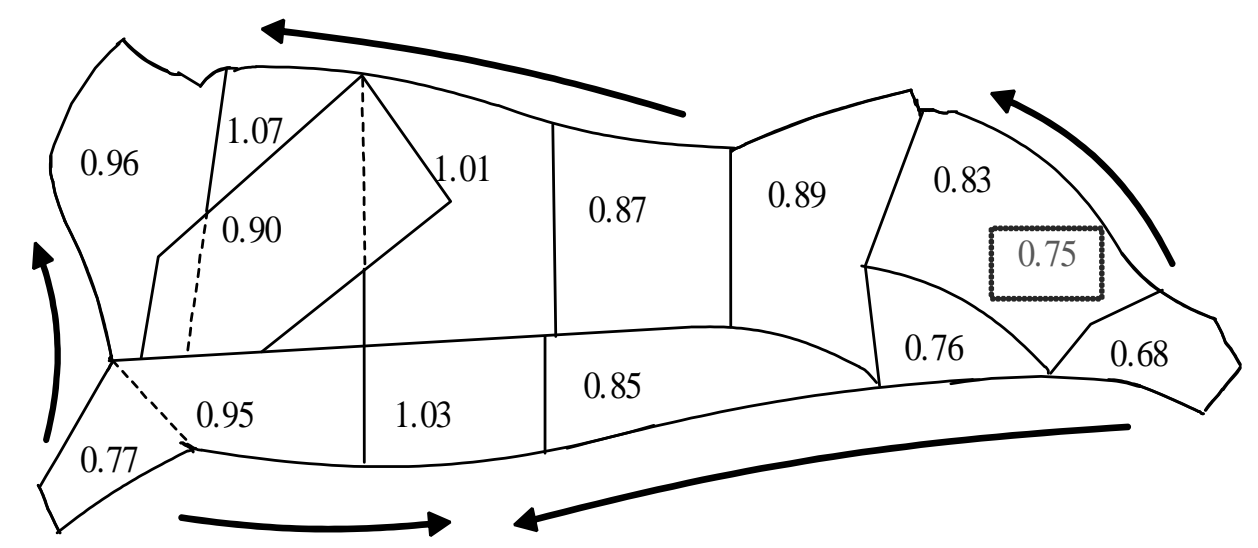

Figure 1. Growth Differentials of Muscles within Wholesale Cuts Relat ive to Gro wth of Carcass

total fat where there was a concentration of growth in ventral region to the dorsal region of the carcass with the lumbar area and Thin Flank as side weight increased. the highest rates of SC fat deposition in the lumbar and With SC fat, there were growth movements from the sacral regions (Rib Set, Loin and Rump). Similar results 
Total Fat

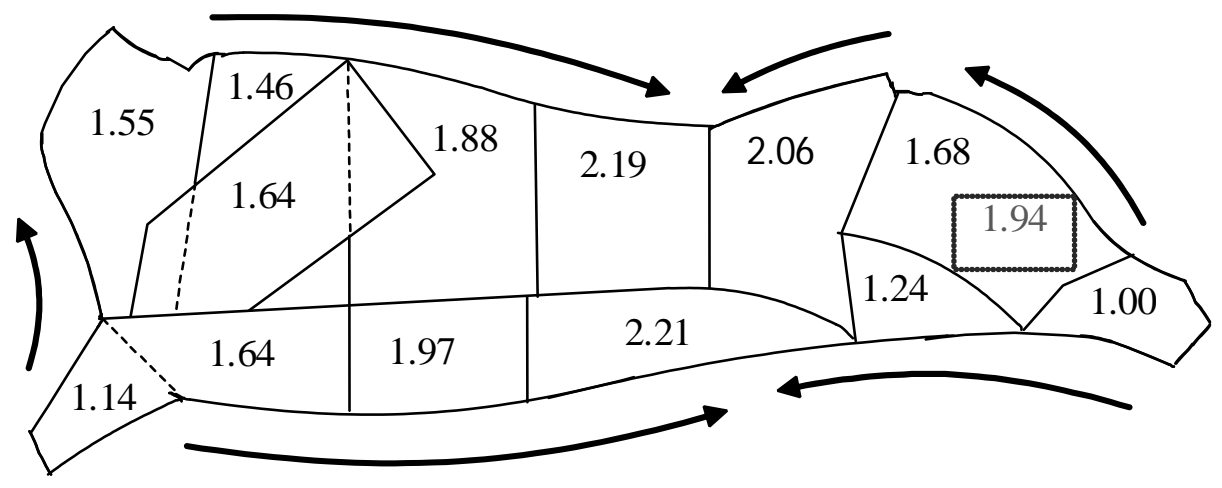

IM Fat

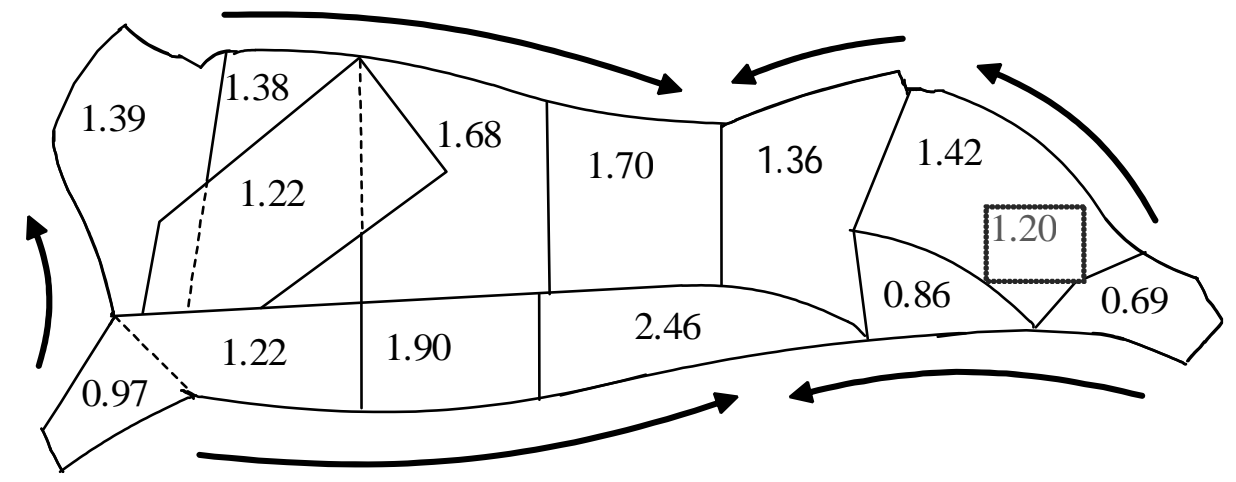

SC Fat

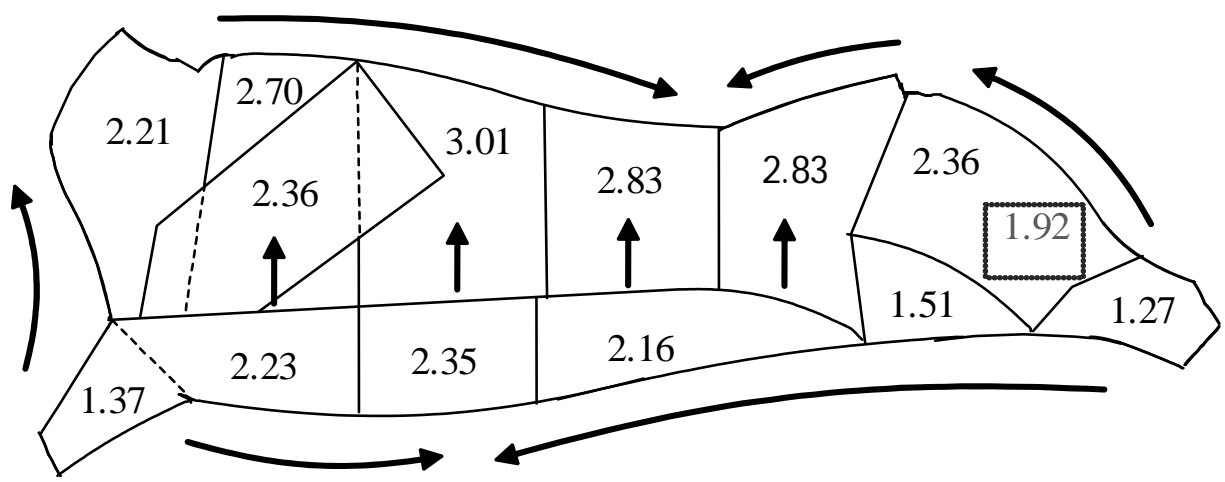

Figure 2. Growth Differentials of Total Fat, IM Fat and SC Fat within Wholesale Cuts Relative to Growth of Carcass

of the developmental patterns for total fat and depot fats (IM and SC fats) have been reported by Jones et al. (1980a) and Belk et al. (1991). This explained the importance of SC fat thicknesses taken on the dorsal area of beef carcass as indicators of carcass composition and beef yield (Johnson et al., 1997; Hafid et al., 2004).

In the literature there was no evidence of studies which compare developmental patterns between tissues.
Rather, the tissue weights in wholesale cuts were related to the total respective tissue in the carcass. Despite this, previous studies of the growth and distribution of individual tissues showed similar developmental tendencies of fat and muscle (Berg et al., 1978ab; Jones et al., 1980ab). In the present study, some differences in growth patterns between muscle and fat were identified especially on the dorsum of the carcass. The 
growth impetus for fat moved from the thoracic region backwards to the lumbar region which was the reverse of the growth pattern in muscle.

Bone growth showed a less clear pattern. However, some growth movements could be identified. Bone in the leg region had the lowest growth coefficient. There was a growth movement from the Shin upward to the thorax and Chuck regions and backwards to the Brisket; another growth movement was evident from the Shank to the proximal hind-limb region (Figure 3).

Overall, Muscle developed from the expensive cuts of the proximal hind-limb region to the less expensive cuts of the proximal fore-limb region. Fat deposition ventral region of the carcass. Muscle growth impetus moved from the hindquarter cuts toward the forequarter cuts while bone growth showed a less clear pattern.

\section{REFERENCES}

AUS-MEAT. 1998. Handbook of Australian Meat. $6^{\text {th }}$ Edition. AUS-MEAT Ltd., Sydney.

Belk, K.E., J.D. Tatum and F. L. Williams, Jr. 1991. Deposition and distribution of carcass fat for steers differing in frame size and muscle thickness. J. Anim. Sci. 69: 609-616.

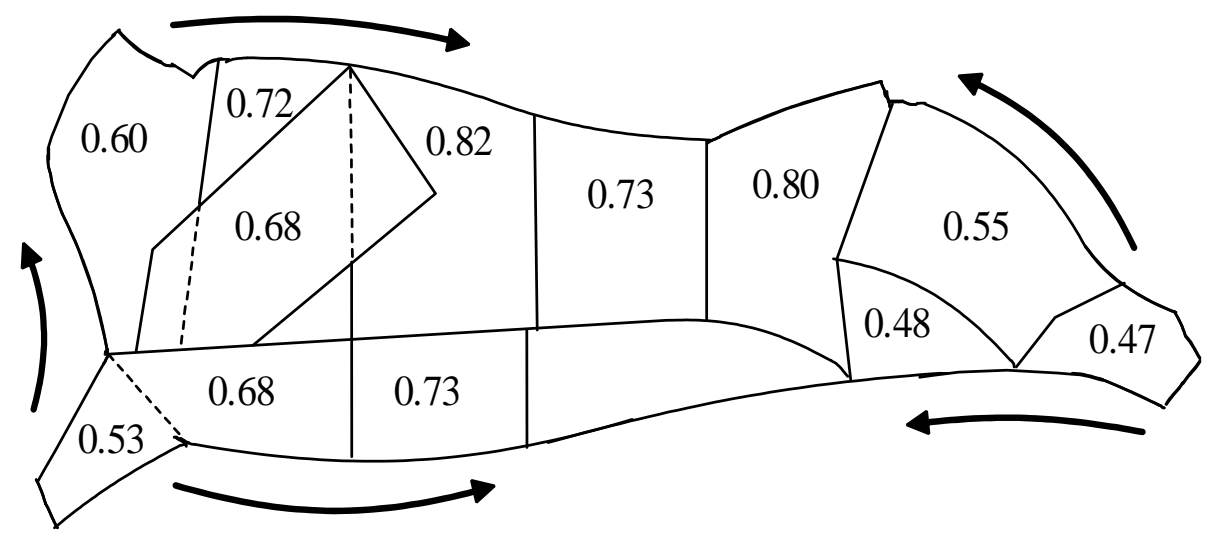

Figure 3. Growth Differentials of Bones within Wholesale Cuts Relative to Growth of Carcas s

was concentrated in the less expensive cuts in the ventral part of carcass as well as in the expensive cuts in the lumbar region, and the fat deposition was much faster than for muscle deposition. Thus, advanced fattening of steers in this study could have a deleterious effect on meat production because of the greater fat accumulation in the carcass and consequently the greater degree of fat trimming.

\section{CONCLUSION}

In fattening steer, there were developmental changes of carcass tissues within wholesale cuts. The changes were mainly due to the differential growth patterns of carcass fat, subcutaneous fat and intermuscular fat, toward the dorsal region as well as
Berg, R.T., B.B. Andersen and T. Liboriussen. 1978a. Growth of bovine tissues. 2. Genetic influence on muscle growth and distribution in young bulls. Anim. Prod. 27: 51-61.

Berg, R.T., B.B. Andersen and T. Liboriussen. 1978b. Growth of bovine tissues. 3. Genetic influence on patterns of fat growth and distribution in young bulls. Anim. Prod. 27: 63-69.

Draper, N. and H. Smith. 1981. Applied Regression Analysis. Second edition. John Wiley and Sons, Brisbane.

Hafid, H., E. Gurnadi, R. Priyanto and A. Saefuddin. 2004. Akurasi penggunaan bobot karkas dan tebal lemak rusuk ke-12 untuk menduga kandungan daging dan lemak karkas pada sapi Australian 
Commercial Cross dan Brahman Cross. AGRIPLUS 14(03): 203-207.

Hafid, H. dan R. Priyanto. 2006. Pertumbuhan dan distribusi potongan komersial karkas sapi Australian Commercial Cross dan Brahman Cross hasil penggemukan. Media Peternakan 29 (2): 63-69

Huxley, J.S. 1932. Problems of Relative Growth. Methuen, London.

Jones, S.D.M., M.A. Price and R.T. Berg. 1978. Effects of breed and sex on the relative growth and distribution of bone in cattle. Can. J. Anim. Sci. 58: 157-165

Jones, S.D.M., M.A. Price and R.T. Berg. 1980a. Fattening patterns in cattle. 2. Fat distribution among the wholesale cuts in bulls and heifers of two breeds. Can. J. Anim. Sci. 60: 851-856

Jones, S.D.M., M.A. Price and R.T. Berg. 1980b. The growth and distribution of muscle in bulls and heifers of two breeds. Can. J. Anim. Sci. 60: 669-675
Johnson, E.R., R. Priyanto and D.G. Taylor. 1997. Investigation into the accuracy of prediction of beef carcass composition using subcutaneous fat thickness and carcass weight II. Improving the accuracy of prediction. Meat Sci. 46: 159-172

Priyanto, R., E.R. Johnson and D.G. Taylor. 1997. Investigation into the accuracy of prediction of beef carcass composition using subcutaneous fat thickness and carcass weight. I. Identifying problems. Meat Sci. 46: 147-157

Priyanto, R., E.R. Johnson and D.G. Taylor. 1999. The economic importance of genotype in steers fed pasture or lucerne hay and prepared for the Australian and Japanese beef markets. NZ J. Agric. Res. 42: 343-404

Priyanto, R. dan H. Hafid. 2005. Identifikasi sifatsifat karkas yang dapat digunakan untuk menduga komposisi karkas sapi. Jurnal Ilmiah Ilmu-Ilmu Peternakan 8(01): 1-9 
